\title{
Pelatihan Penyusunan Standard Operating Procedure (SOP) Keuangan Bagi Pengelola BUMDes Desa Karang Bayan Kecamatan Lingsar Kabupaten Lombok Barat
}

\section{Dwi Putra Buana Sakti*, Siti Nurmayanti, I Nyoman Nugraha Ardana Putra, Laila Wardani}

Program Studi Manajemen Fakultas ekonomi dan Bisnis

Universitas Mataram, Kota Mataram, Indonesia

\begin{abstract}
Kata Kunci: BUMDes, Standard Operating Procedure (SOP), Pelatihan

Abstrak: Permasalahan utama yang dihadapi BUMDES Desa Karang Bayan adalah ketiadaan Standard Operating Procedure (SOP) keuangan yang berimplikasi pada stagnannya perkembangan BUMDES tersebut. Tersedianya SOP keuangan yang terdokumentasi sangat diperlukan untuk memandu pengelolaan BUMDES. Untuk itu perlu diberikan pelatihan penyusunan SOP keuangan. Kegiatan ini ditujukan untuk memberikan kemampuan menyusun SOP keuangan melalui pelatihan bagi pengelola BUMDES Desa Karang Bayan. Metode pelaksanaan kegiatan dilakukan dalam bentuk pelatihan singkat kepada 20 peserta yang dilaksanakan di kantor Kepala Desa Karang Bayan. Hasil yang dicapai setelah pelatihan ini adalah: (i) pengelola BUMDES Desa Karang Bayan mampu menyusun SOP keuangan; (ii) pengelola BUMDES Desa Karang Bayan memiliki pemahaman yang benar tentang rancang bangun bisnis dan pengelolaan BUMDES
\end{abstract}

\section{Korespondensi: dwiputrabs@unram.ac.id}

\section{PENDAHULUAN}

Pendirian Badan Usaha Milik Desa (BUMDes) merupakan salah satu upaya mewadahi inisiatif masyarakat desa, mengembangkan potensi desa, mengelola dan memanfaatkan potensi sumber daya alam desa sekaligus mengoptimalkan sumber daya manusia (warga desa) dalam pengelolaannya. Desa Karang Bayan adalah salah satu desa yang telah memiliki Badan Usaha Milik Desa (BUMDes. Desa ini merupakan pemekaran dari desa Sigerongan Kecamatan Lingsar Kabupaten Lombok Barat. Terletak kurang lebih tujuh kilometer dari ibukota Propinsi Nusa Tenggara Barat. Memiliki luas wilayah 1.535,6 hektar, desa ini memiliki hawa yang cukup sejuk karena terletak di ketinggian $116 \mathrm{~m}$ dpl. Berdasarkan potensi yang dimilikinya, BUMDes Desa Karang Bayan memiliki prospek yang bagus untuk tumbuh dan berkembang menjadi sebuah BUMDes maju guna menuju kemandirian ekonomi desa, menopang sumber pendapatan desa, dan wadah guna sebagai produksi kerajinan dan kreasi lokal masyarakat desa yang akan berbuah nilai ekonomi bagi masyarakatnya.

Prospek BUMDes Desa Karang Bayan untuk tumbuh dan berkembang menjadi BUMDes maju didukung oleh: (1) Adanya kewenangan bagi kepala desa bersama badan pemusyawaratan desa untuk membentuk peraturan desa sebagaimana diatur dalam UU No. 6 Tahun 2015 tentang Desa, yang dapat menjadi dasar hukum pembentukan BUMDes oleh Pemerintah Desa Karang Bayan; (2) Adanya kebijakan strategis nasional (Nawa Cita) dan lokal tentang kemandirian ekonomi desa melalui pembentukan dan pengelolaan BUMDes; (3) Adanya anggaran dana desa yang cukup besar yang sebagiannya dapat dialokasikan untuk 
dana modal produksi dan pengelolaan sampai pemasaran hasil produksi BUMDes; (4) Adanya keinginan pemerintah desa untuk memberdayakan masyarakat desa melalui BUMDes menuju kemandirian ekonomi desa. Hal itu terlihat dari adanya rencana kepala desa untuk merevitalisasi BUMDes yang ada.

Berdasarkan informasi yang disampaikan oleh Kepala Desa Karang Bayan dalam kesempatan mendampingi kelompok mahasiswa KKN pada tanggal 21 Januari 2019 yang lalu, keberadaan BUMDes Desa Karang Bayan ibarat pepatah "hidup segan mati tak mau". Sejak didirikan pada tahun 2008 hingga saat ini, BUMDes Desa Karang Bayan tidak dikelola berdasarkan Standard Operating Procedure (SOP) yang jelas.

Standard Operating Procedure (SOP) adalah dokumen yang berisi serangkaian instruksi tertulis yang dibakukan mengenai berbagai proses penyelenggaraan administrasi perkantoran yang berisi cara melakukan pekerjaan, waktu pelaksanaan, tempat penyelenggaraan dan aktor yang berperan dalam kegiatan (Insani, 2010:1).

SOP memiliki manfaat bagi organisasi antara lain (Permenpan No.PER/21/MPAN/11/2008): (i) Sebagai standardisasi cara yang dilakukan pegawai dalam menyelesaikan pekerjaan khusus, mengurangi kesalahan dan kelalaian; (ii) SOP membantu staf menjadi lebih mandiri dan tidak tergantung pada intervensi manajemen, sehingga akan mengurangi keterlibatan pimpinan dalam pelaksanaan proses sehari-hari; (iii) Meningkatkan akuntabilitas dengan mendokumentasikan tanggung jawab khusus dalam melaksanakan tugas; (iv) Menciptakan ukuran standar kinerja yang akan memberikan pegawai. cara konkret untuk memperbaiki kinerja serta membantu mengevaluasi usaha yang telah dilakukan; (v) Menciptakan bahan-bahan training yang dapat membantu pegawai baru untuk cepat melakukan tugasnya; (vi) Menunjukkan kinerja bahwa organisasi efisien dan dikelola dengan baik; (vii) Menyediakan pedoman bagi setiap pegawai di unit pelayanan dalam melaksanakan pemberian pelayanan sehari-hari; (viii) Menghindari tumpang tindih pelaksanaan tugas pemberian pelayanan; (ix) Membantu penelusuran terhadap kesalahan-kesalahan prosedural dalam memberikan pelayanan. Menjamin proses pelayanan tetap berjalan dalam berbagai situasi.

Permasalahan yang dihadapi BUMDes terkait dengan pengelolaan usaha telah banyak menarik perhatian sejumlah pengabdi. Musafa, Hernawan dan Dewi (2018) menemukan permasalahan terkait dengan pengelolaan keuangan BUMDes Desa Girimekar Kecamatan Cilengkrang Kabupaten Bandung yang bersumber dari kualitas sumberdaya manusia yang belum memiliki kemampuan dan keahlian dalam bidang akuntansi. Sekaitan dengan itu, Musafa dkk. (2018) melaksanakan kegiatan pengabdian dalam bentuk workshop manual dan digital accounting bagi pengelola BUMDes Desa Girimekar.

Profesionalisme dalam mengelola BUMDes juga menarik perhatian Sakti, Nurmayanti, Putra, Suparman dan Hermanto (2018) untuk melaksanakan pengabdian kepada masyarakat yang ditujukan bagi pengelola BUMDes Mart Desa Sokong Kecamatan Tanjung Kabupaten Lombok Utara. Melalui kegiatan penyuluhan, Sakti dkk. (2018) mengenalkan pentingnya manajemen ritel dalam mengelola BUMDes. Demikian pula Hidayah, Mulyana, Susanti dan Pujiastuti (2018) melaksanakan kegiatan pengabdian masyarakat berupa pendampingan pengelolaan BUMDes dalam kaitannya sebagai infant organisasi. Kegiatan yang dilaksanakan Hidayah dkk. (2018) berhasil membantu pengelola BUMDes Mitra Jaya 
Mandiri Desa Cinangka Kecamatan Cinangka Kabupaten Serang untuk menyusun SOP, pembukuan keuangan menggunakan aplikasi dan membuat uruaian jabatan BUMDes

Berdasarkan uraian di atas, disadari bahwa adanya Standard Operating Procedure (SOP) keuangan menjadi urgen untuk memandu pengelolaan keuangan BUMDes Desa Karang Bayan agar terlepas dari situasi yag dihadapi sampai saat ini. Beberapa masalah yang teridentifikasi adalah: (i) Tidak ada SOP keuangan yang menjadi panduan bagi pengelolaan keuangan BUMDes; (ii) pengelola BUMDes tidak bisa menyusun SOP; (iii) pengelola BUMDes memiliki pemahaman yang terbatas tetang pengelolaan usaha.

Merujuk pada permasalahan yang dihadapi oleh BUMDes Desa Karang Bayan tersebut, diperlukan suatu kegiatan yang bersifat aplikatif dan memiliki output terukur dan jelas. Dalam konteks program pengabdian ini, salah satu kegiatan yang dilakukan adalah berbentuk pelatihan penyusunan Standard Operating Procedure (SOP) keuangan dalam pengelolaan Badan Usaha Milik Desa (BUMDes). Solusi yang ditawarkan melalui kegiatan ini adalah: (i) tersedianya SOP sebagai panduan pengelolaan keauangan BUMDes ; (ii) pengelola BUMDes mampu menyusun SOP keuangan; (iii) Meningkatnya pengetahuan pengelola BUMDes tentang pengelolaan usaha.

\section{METODE KEGIATAN}

Pelaksanaan kegiatan pengabdian kepada masyarakat bagi pengelola BUMDes Desa Karang Bayan Kecamatan Lingsar Kabupaten Lombok Barat dilakukan dalam bentuk pelatihan, melalui tahapan:

A. Persiapan

Pada tahap persiapan, tim pengabdian kepada masyarakat melakukan pra survey ke BUMDes Desa Karang Bayan terkait permasalahan yang dihadapi. Tim pengabdi menemukan kenyataan bahwa SOP yang seharusnya menjadi pedoman pengelolaan keuangan BUMDes tidak ada. Berdasarkan temuan tersebut, tim kemudian menemui Kepala Desa Karang Bayan untuk membicarakan pelaksanaan kegiatan pengabdian kepada masayarakat di wilayahnya. Pada kesempatan itu juga disepakati: (i) waktu dan tempat pelaksanaan; dan (ii) jumlah peserta.

B. Pelaksanaan Pelatihan

Pelatihan penyusunan SOP keuangan dilaksanakan di gedung pertemuan Kantor Desa Karang Bayan selama 3 hari pada hari Kamis 29 Agustus sampai dengan Sabtu 31 Agustus 2019. Peserta yang hadir sebanyak 14 orang. Pada tahap ini, metode kegiatan yang digunakan meliputi: (i) ceramah, mejelaskan materi tentang pentingnya SOP bagi organisasi; (ii) diskusi, dengan memberikan kesempatan kepada peserta untuk mengajukan pertanyaan terkait materi yang diterima; (iii) pelatihan menyusun SOP keuangan yang diperlukan dalam pengelolaan BUMDes.

\section{HASIL DAN PEMBAHASAN}

Hasil yang dicapai dalam penyelesaian masalah yang dihadapi BUMDes Desa Karang Bayan melalui pelatihan selama 3 hari adalah:

a. Tim pelaksana pengabdian kepada masyarakat berhasil menumbuhkan kesadaran pada Kepala Desa dan pengelola BUMDes Desa Karang Bayan tentang urgensi penyusunan 
SOP sebagai panduan dalam mengelola keuangan BUMDes melalui pelatihan yang dilaksanakan di gedung pertemuan Kantor Desa Karang Bayan yang dihadiri oleh Kepala Desa, Sekretaris Desa, Ketua dan Anggota Pengurus Bumdes, Ketua PAMDes, Ketua Pokdarwis dan Ketua Karang Taruna Desa Karang Bayan.

b. Tim pelaksana pengabdian kepada masyarakat berhasil melatih pengelola BUMDes Desa Karang Bayan untuk menyusun SOP yang selanjutnya menjadi pedoman dalam pengelolaan keuangan BUMDes.

c. Tim Pelaksana Pengabdian Masyarakat berhasil meningkatkan pemahaman pengelola BUMDes untuk membantu mereka mengelola usaha dengan cara yang lebih professional.

d. Sebagai tindak lanjut pelatihan yang dilaksanakan, Kepala Desa Karang Bayan memfasilitasi pembangunan gedung BUMDES Desa Karang Bayan beserta fasilitas yang dibutuhkan

Tim melakukan evaluasi dalam bentuk evaluasi proses dan evaluasi hasil. Evaluasi terhadap proses meliputi keseriusan, ketekunan dan perhatian yang diberikan peserta selama mengikuti pelatihan. Selama penyampaian materi berlangsung, peserta pelatihan bersungguhsungguh mengikuti hinga berakhir. Pertanyaan-pertanyaan segera diajukan peserta apabila mereka belum mengerti materi yang disampaikan atau contoh-contoh yang ditampilkan narasumber. Evaluasi terhadap hasil dilakukan untuk mengetahui tingkat penerimaan peserta terhadap materi pelatihan. Berdasarkan evaluasi terhadap hasil, tampak bahwa peserta merasakan kesulitan ketika materi pelatihan yang berkaitan dengan prosedur akuntansi. Hampir semua peserta pelatihan, hingga sejauh ini hanya mengenal pembukuan sederhana. Itu sebabnya, di akhir kegiatan peserta berharap keberlanjutan program dalam bentuk pendampingan karena mereka merasakan manfaat kegiatan yang diikuti.

Beberapa faktor yang mendukung keberhasilan kegiatan ini adalah: (1) Dukungan penuh dari Kepala Desa Karang Bayan, berupa menyediakan ruangan pelatihan beserta kelengkapannya seperti: meja untuk narasumber, kursi, pengeras suara, lcd, laptop dan papan tulis; (2) Komitmen yang tinggi dari peserta pelatihan, dalam bentuk kehadiran penuh selama tiga hari. Selama tiga berturut-turut, peserta sangat antusias menyimak materi yang disampaikan narasumber serta aktif terlibat dalam tanya jawab; (3) Koordinasi tim. Tim melakukan komunikasi dan koordinasi yang baik sejak tahap persiapam hingga terlaksananya kegiatan. Masing-masing anggota tim mengambil peran yang signifikan sesuai dengan kompetensi yang dimiliki.
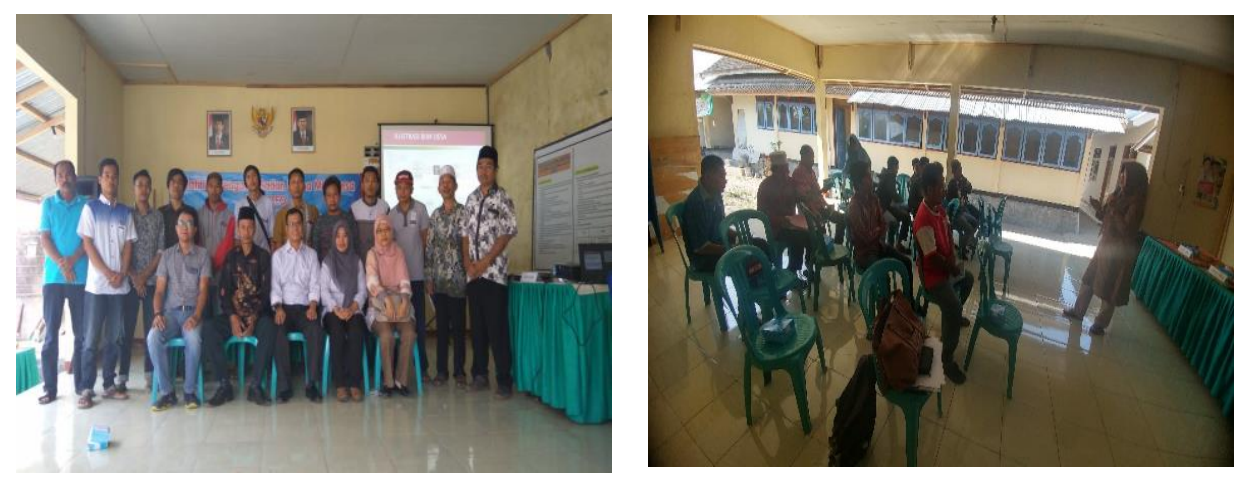

Gambar 1. Narasumber Bersama peserta pelatihan 
Disisi lain, faktor yang menjadi penghambat keberhasilan kegiatan ini adalah rendahnya pemahaman peserta tentang praktik akuntansi. Keragaman latar belakang pendidikan peserta pelatihan menjadi penyebabnya. Pemahaman yang rendah berimbas pada alokasi waktu yang cukup banyak tersita untuk memberikan pemahaman terkait dasar-dasar akuntansi.. Namun demikian, terlepas dari hal-hal tersebut, peserta menunjukkaan antusiasme yang tinggi untuk mengikuti pelatihan.
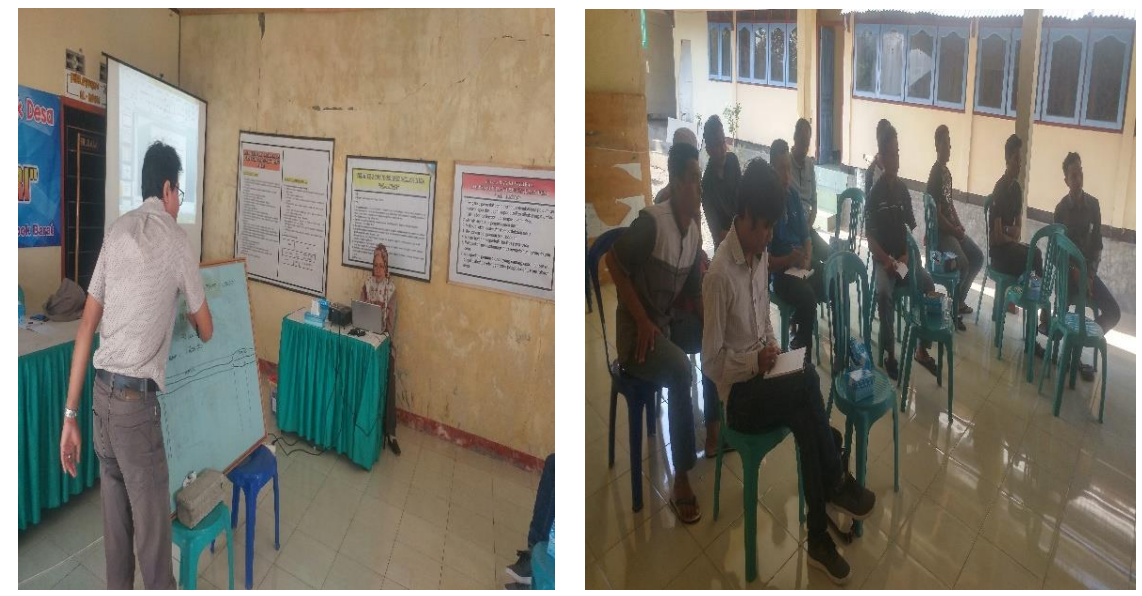

Gambar 2. Peserta pelatihan serius menyimak materi yang disampaikan narasumber

\section{KESIMPULAN DAN SARAN}

Dari seluruh rangkaian kegiatan pelatihan yang dilakukan, disimpulkan bahwa BUMDes Desa Karang Bayan hingga saat ini belum memiliki Standard Operating Procedure (SOP) keuangan sebagai panduan mengelola keuangan usaha. Hal ini menyebabkan kondisi BUMDes Desa Karang Bayan ibarat pepatah hidup tak mau matipun segan.

Melalui kegiatan pelatihan penyusunan SOP keuangan yang dilakukan oleh tim pengabdi kepada masyarakat, pengelola BUMDes Desa Karang Bayan mampu menyusun SOP keuangan. Adanya SOP keuangan memberikan manfaat sebagai berikut: (i) Sebagai standardisasi cara yang dilakukan pengelola BUMDes dalam melaporkan keuangan,; (ii) Meningkatkan akuntabilitas dengan mendokumentasikan tanggung jawab khusus dalam melaksanakan tugas; (iii) Menunjukkan bahwa keuangan BUMDes dikelola secara baik dan efisien; (iv) Menghindari tumpang tindih pengelolaan keuangan BUMDes; (v) Membantu penelusuran terhadap kesalahan-kesalahan prosedural dalam mengelola keuangan BUMDes.

Merujuk pada simpulan diatas maka disarankan kepada pengelola BUMDes untuk menerapkapkan prosedur-prosedur yang tertuang dalam SOP keuangan yang telah disusun.

\section{Ucapan Terima Kasih}

Tim pengabdi menyampaikan terimakasih kepada Fakultas Ekonomi dan Bisnis Universitas Mataram serta Lembaga Penelitian dan Pengabdian Kepada Msyarakat Universitas Mataram yang mendanai pelaksanaan pengabdian kepada masyarakat hingga dapat terlaksana dengan baik sesuai kontrak pengabdian nomor: 2276/UN18/LPPM/2019. 


\section{DAFTAR PUSTAKA}

Hidayah, Z., Mulyana, A., Susanti, E., Pujiastuti, S.L.P, (2018), Pendampingan Pengelolaan Badan Usaha Milik Desa (Bumdes) Dalam Kaitannya Sebagai Infant Organisasi, Prosiding Seminar Nasional Pengabdian Kepada Masyarakat Universitas Terbuka 2018, Tangerang Selatan, 30 Oktober 2018.

Insani, Istyadi, (2010), Pengembangan Kapasitas Sumber Daya Manusia Daerah Dalam Rangka Peningkatan Transparansi dan Akuntabilitas Pengelolaan Keuangan Daerah.

Musafa, Hernawan, Y., Dewi, S.Y.K, (2018), Workshop Manual \& Digital Accounting Pada Badan Usaha Milik Desa Girimekar, JURNAL ABDIMAS BSI, 1 (2) 322-333, diambil dari: https://ejournal.bsi.ac.id/ejurnal/index.php/abdimas/article/view/3917

Permen PAN Nomor: PER/21/M.PAN/11/2008 tentang Pedoman Penyusunan Standar Operasional Prosedur Administrasi Pemerintahan.

Sakti, D.P.B, Nurmayanti, S., Suparman, L., Hermanto, (2018), Meningkatkan Profesionalisme Melalui Penyuluhan Manajemen Ritel Bagi Pengelola BUMDes Mart Desa Sokong, Prosiding Pengabdian Kepada Masyarakat FEB Unram 2018, diambil dari: $\quad$ http://eprints.unram.ac.id/10626/1/ARTIKEL_PENGABDIAN-

DESA_SOKONG.pdf 